\title{
Population structure of the shrimp Palaemon pandaliformis (Stimpson, 1871) (Caridea: Palaemonidae) in the river Rio Itapemirim, in Southeastern Brazil
}

\author{
Pedro de Souza Laino ${ }^{1 *} \mathbb{D}^{-}$, Joelson Musiello-Fernandes ${ }^{1} \mathbb{1}$ \& Adriane Araujo Braga $^{2}$ \\ ${ }^{1}$ Universidade Federal do Espírito Santo, Programa de Pós-Graduação em Oceanografia Ambiental, Vitória, ES, Brasil. \\ ${ }^{2}$ Universidade Federal do Espírito Santo, Centro de Ciências Exatas, Naturais e da Saúde, Vitória, ES, Brasil. \\ *Corresponding author: Pedro Laino, e-mail: lainops@gmail.com
}

LAINO, P.S., MUSIELLO-FERNANDES, J., BRAGA, A.A. Population structure of the shrimp Palaemon pandaliformis (Stimpson, 1871) (Caridea: Palaemonidae) in the river Rio Itapemirim, in Southeastern Brazil. Biota Neotropica 20(4): e20201020. https://doi.org/10.1590/1676-0611-BN-2020-1020

\begin{abstract}
The present study analyzes the population structure of Palaemon pandaliformis, based on sex ratio, the frequency distribution in defined size classes and the reproductive biology of samples captured in seasonal collections (winter 2011 to autumn 2012) with sieves under marginal vegetation. A total of 1,043 specimens were obtained, 222 juveniles, 465 males and 356 females, being that of this total of females, $58.42 \%$ were in the ovigerous condition. The average size of the carapace for both sexes varied between 4 and $6 \mathrm{~mm}(\mathrm{p}>0.05)$ only the ovigerous females had higher averages $(p<0.0001)$. The sex ratio differed with 1:0.76 for males $(p=0.0001)$, although juvenile individuals and females were present in all sampled periods, except ovigerous females in autumn. Highest abundances were observed during the winter and spring period $(\mathrm{p}=0.0001)$, decreasing in the periods with higher water temperature and salinity (summer and autumn). Was observed a continuous recruitment due to the presence of juveniles in all seasons, with greater abundance in winter and spring. Thus, based on the presence of ovigerous females in almost all seasons and juveniles in all, the reproduction for $P$. pandaliformis can be defined as seasonal-continuous with peak in winter period.
\end{abstract}

Keywords: freshwater prawns; population dynamics; sex ratio; reproductive period.

\section{Estrutura populacional do camarão Palaemon pandaliformis (Stimpson, 1871) (Caridea: Palaemonidae) no Rio Itapemirim, sudeste do Brasil}

Resumo: O presente estudo analisou a estrutura populacional de Palaemon pandaliformis, com base na razão sexual, distribuição de frequência em classe de tamanho e biologia reprodutiva de amostras capturadas em coletas sazonais (inverno/2011 a outono/2012), com peneiras sob a vegetação marginal. Um total de 1.043 exemplares foi obtido, sendo 222 juvenis, 465 machos e 356 fêmeas, sendo que deste total de fêmeas, 58.42 \% estavam na condição ovígeras. O tamanho médio da carapaça, para ambos os sexos, variou entre 4 e $6 \mathrm{~mm}$ $(p>0,05)$, apenas as fêmeas ovígeras apresentaram maiores médias $(p<0,0001)$. A razão sexual diferiu em 1:0,76 para machos $(\mathrm{p}=0,0001)$, embora os indivíduos jovens e as fêmeas estiveram presentes em todos os períodos amostrados, exceto as fêmeas ovígeras no outono. As maiores abundâncias foram observadas durante o período de inverno e primavera $(\mathrm{p}=0,0001)$, diminuindo nos períodos de maior temperatura e salinidade da água (verão e outono). Foi observado um recrutamento contínuo devido a presença de juvenis em todas as estações, com maior abundância no inverno e primavera. Assim, com base na presença de fêmeas ovígeras em quase todas as estações e juvenis em todas, a reprodução de $P$. pandaliformis pode ser definida como sazonal-contínua, com pico no período do inverno.

Palavras-chave: camarão de água doce; dinâmica populacional; razão sexual; período reprodutivo. 


\section{Introduction}

Population studies of crustaceans provide relevant information on the dynamics and preservation of the studied species. This knowledge and a clear characterization of species are fundamental for measures aimed at the maintenance and conservation of natural resources and the understanding of their ecological stability. Variations in the different aspects of ecological stability, such as birth-death-ratio, density, sex ratio, reproductive aspects or growth and migration, are commonly observed and quantified in population studies (Costa \& NegreirosFransozo 2003.

The families Atyidae and Palaemonidae are the most common ones among freshwater carideans. In Brazil, the palaemonids are mainly represented by the genera Macrobrachium (Spence Bate, 1868) and Palaemon (Weber, 1795) known as freshwater prawns (Carvalho et al. 1979, Bond-Buckup \& Buckup 1989, Valenti et al. 1989).

Representatives of the species Palaemon pandaliformis (Stimpson, 1871) are small carideans prawns found in fresh and salt water environments from Guatemala to southern Brazil (Melo 2003, Ferreira et al. 2010). Individuals of this species, as well as a large part of the Palaemonidae, are osmoregulators (Freire et al. 2003). They can support variations in salinity, which allows them to explore environments from freshwater to estuaries, often found next to aquatic or marginal vegetation (Mortari \& Negreiros-Fransozo 2007).

Although $P$. pandaliformis is not officially used for commercial purposes nor makes part of the human diet, this species is still widely exploited as live bait in artisanal fisheries (Müller et al. 1996). However, it is a species that is also an important part of the trophic chain, serving as food for various invertebrates, fish and birds (Mortari \& NegreirosFransozo 2007).
Despite its important ecological role, the work related to the biology of the species is still unsatisfactory. Only few studies have been published addressing its reproductive biology (Lima \& Oshiro 2002, Mortari et al. 2009, Rosa et al. 2015), ecological aspects (Müller et al. 1996, Mortari \& Negreiros-Fransozo 2007) and sexual maturity (Anger \& Moreira 1998, Paschoal et al. 2013). In Southeastern Brazil and especially in the State of Espírito Santo, a deeper analysis of the species dynamics of the shrimp P. pandaliformis are necessary in order to understand the importance of this species for the balance of an ecosystem of rivers and estuaries. Thus, the objective of this study was to analyze the population structure of these shrimps by surveying and studying data regarding their abundance, frequency distribution in size classes, sex ratio, seasonal recruitment of juveniles and the reproductive period based on the presence of ovigerous females.

\section{Material and methods}

The shrimps associated with partially submerged marginal vegetation were captured in seasonal collections (winter: September 2011; spring: November 2011; summer: March 2012; autumn: June 2012). Two samplings were performed per period, in order to cover a larger area of capture and obtain replicates, totaling eight samples.

The collection points were set on a river arm close to the mouth of the river Rio Itapemirim (2059'48.0"S; $\left.40^{\circ} 48^{\prime} 53.8^{\prime \prime} \mathrm{W}\right)$, in the municipality of Marataízes, located at the south coast of the State of Espírito Santo, Southeast Brazil (Figure 1). The collections were carried out during low tide (between 0.0 and $0.1 \mathrm{~m}$ ) during the day and were performed actively by a collector with the aid of a $2 \mathrm{~mm}$ mesh sieve for 25 minutes in each sampling.

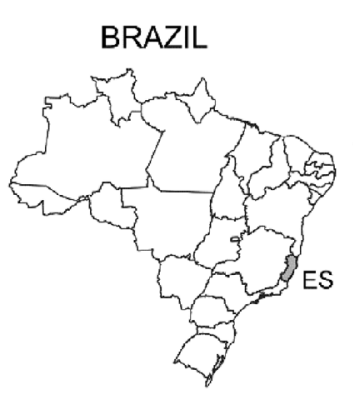

ESPÍRITO SANTO

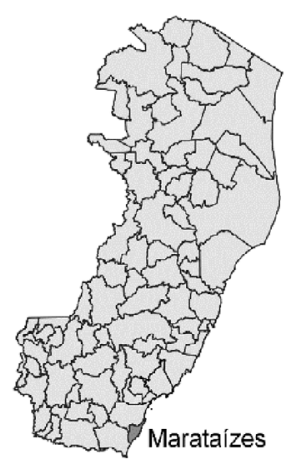

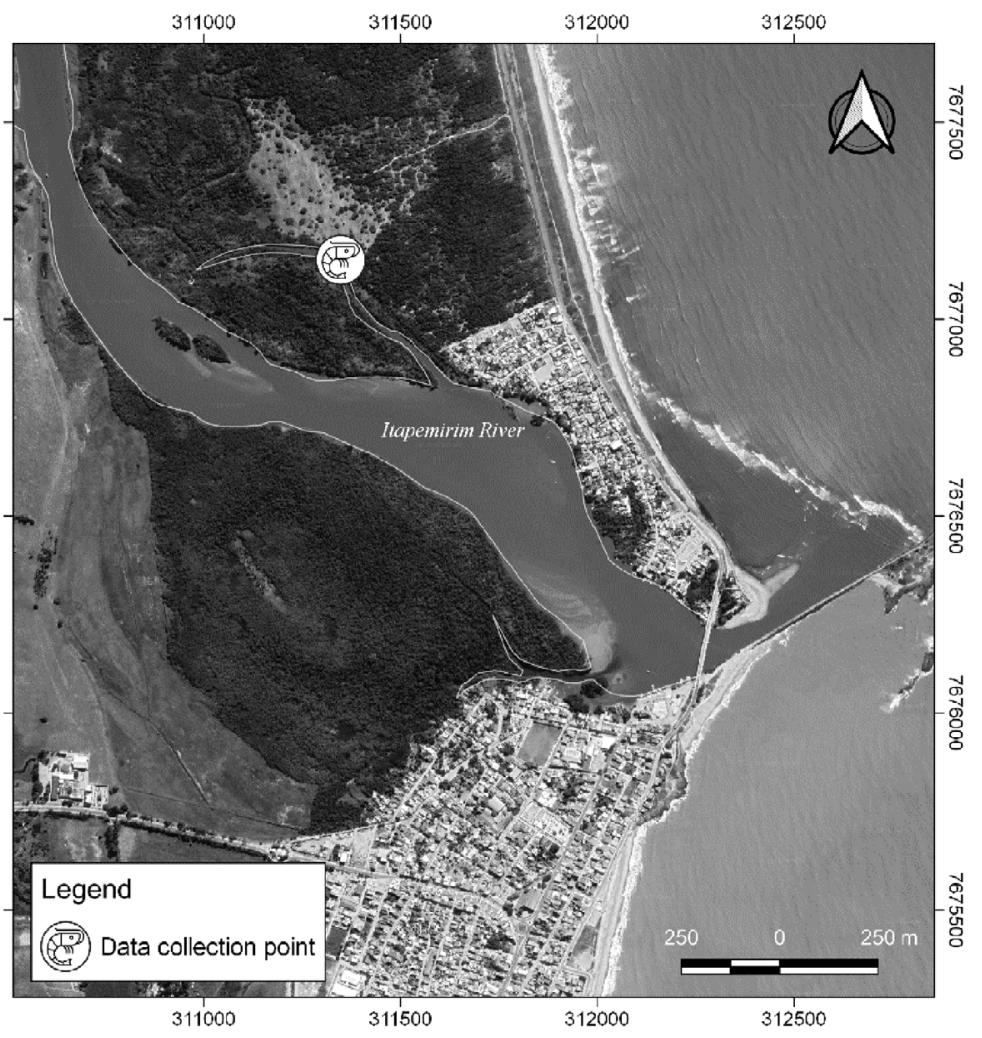

Figure 1. Collection point of Palaemonid shrimps in the river Rio Itapemirim/Marataízes, Espírito Santo, located in the southeast of Brazil between winter 2011 and autumn 2012. 
The following environmental factors were analyzed during all collections: water temperature $\left({ }^{\circ} \mathrm{C}\right)$, water salinity and depth were measured using a mercury thermometer, manual refractometer (\%o) and measuring tape, respectively.

The samples of each point were grouped for a better analysis, considering proximity and the similarity of the environmental parameters in each sampling.

In the laboratory, the specimens were screened and identified (Melo 2003). Sexing was performed based on two characters: 1. the location of male and female gonopores located at the base of the 5th and 3rd pair of pereiopods, respectively; and 2. the morphology of the secondary sexual characters (in male individuals, the presence of the male appendix in the endopodite of the second pair of pleopods). In addition, females with eggs adhered to the pleopods located in the abdomen were registered (Bauer 2004).

For each collected individual, we measured the length of the carapace $(\mathrm{CC}$, distance from the posterior margin of the orbit to the posterolateral margin of the carapace) with a digital caliper (0.01 $\mathrm{mm}$ ). Following the work of Rosa et al. (2015), we separated juveniles from adult individuals (males, non-ovigerous females and ovigerous females) based on the size of the smallest ovigerous female we collected. Subsequently, we grouped the palaemonids into size classes with an amplitude of $1 \mathrm{~mm}$, and visualized their frequency distribution for each sex with a histogram.

The average carapace length of the palaemonid shrimp was compared statistically using the Mann-Whitney test (Hammer et al. 2001). An analysis of variance (one-way ANOVA) was used to verify the existence of a possible difference between the abiotic factors (temperature and salinity) and between the constituent groups of the population (juvenile, males, non-ovigerous females and ovigerous females). Another analysis (two-way ANOVA) verified the average catches of palaemonid shrimp throughout the seasons. In the correlation between abiotic data (temperature and salinity) and data related to the abundance of palaemonids capture, we used the Pearson's coefficient and considered $\mathrm{p} \leq 0.05$ to be significant.

The sex ratio of the population (1:1) was determined by sampling the collected adult individuals, followed by the Chi-square test $\left(X^{2}\right)(\alpha$ $=5 \%)($ Zar 2010). Recruitment was verified through the proportion of juveniles in relation to the total of sampled adult individuals, whereas the reproductive period was analyzed through the percentage of ovigerous females in relation to the total of adult females registered in each season. The analyses of the tests were performed using the PAST statistical package at the level of $5 \%$ of significance (Hammer et al. 2001).

\section{Results}

The water temperature presented a seasonal fluctuation (one-way ANOVA, $p=0.015$ ), varying between 25 and $27^{\circ} \mathrm{C}$ in winter, spring and autumn, and being stable at $29^{\circ} \mathrm{C}$ during summer. The same seasonality was found for the water salinity (one-way ANOVA $p$ $<0.001$ ), which showed a variation of up to 2 PSU over the seasons, except in summer when 9 PSU were registered (Figure 2). The correlation analysis showed a strong positive linear association between temperature and salinity variables $(r=0.782 ; \mathrm{p}=0.021)$. The depth of the collection site did not vary (average of 1.3 meters, one-way ANOVA, $\mathrm{p}>0.05$ ).

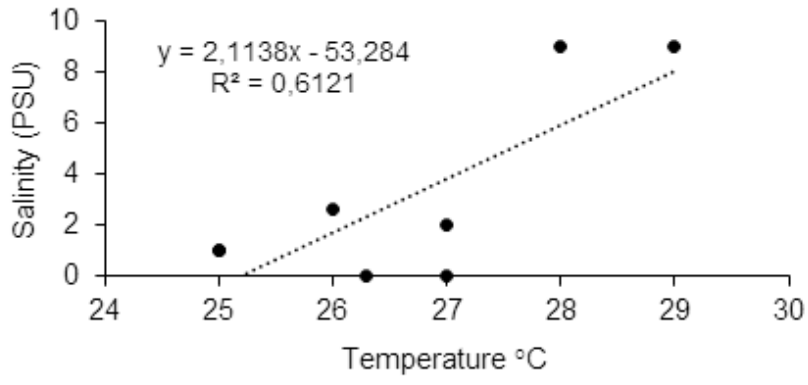

Figure 2. Seasonal variation and correlation of temperature $\left({ }^{\circ} \mathrm{C}\right)$ and salinity $(\% 0$ of the water from the river Rio Itapemirim/Marataízes, Espírito Santo, located in the southeast of Brazil between winter 2011 and autumn 2012.

During the study period, a total of 1,043 individuals of $P$. pandaliformis were obtained: 222 juveniles (21.28\%), 465 males (44.58\%) and 356 females total (34.14\%), of which 208 had eggs adhered to their pleopods (ovigerous females - 58.42\%) (one-way ANOVA; $p>0.05)$. The largest numbers of shrimp were caught in winter and spring of 2011 (two-way ANOVA; $p=0.0001$ ) (Figure 3). The results of the Pearson's correlation showed no significant relationship between the variation of temperature $(\mathrm{r}=-0.66 ; \mathrm{p}=0.069)$ and salinity $(\mathrm{r}=-0.46 ; \mathrm{p}=0.24)$ with the abundance of $P$. pandaliformis (Figure 4$)$.

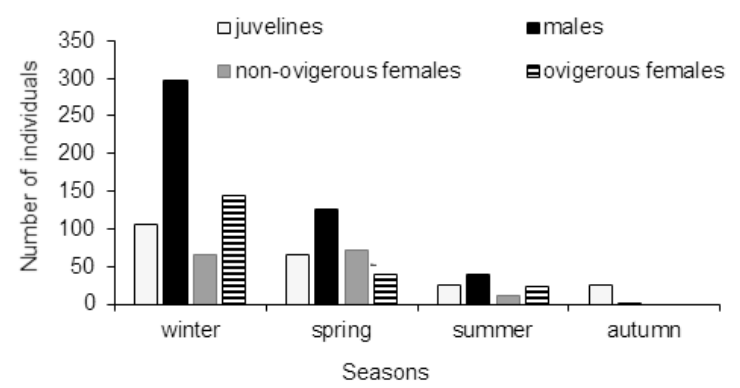

Figure 3. Number of individuals of Palaemon pandaliformis collected seasonally in an estuary in southeast Brazil between winter 2011 and autumn 2012.
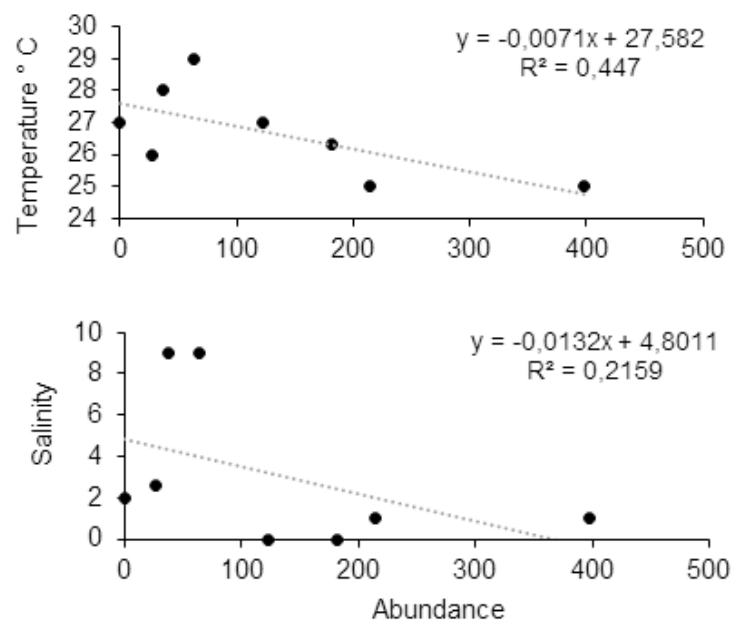

Figure 4. Correlation of abiotic factors (temperature and salinity) with the abundance of Palaemon pandaliformis collected seasonally in an estuary in southeast Brazil between winter 2011 and autumn 2012. 
Most of the captured male individuals (39\%) as well as the nonovigerous females $(12 \%)$ presented a carapace length varying between 4 to $6 \mathrm{~mm} \mathrm{CC}$, with no significant difference between the average size between the sexes $(U=32251 ; p=0.2487)$ (Figure 5). For the ovigerous females, a greater amplitude in the carapace length was observed, with preferential distribution between classes 4-5 and 6-7 $\mathrm{mm} \mathrm{CC}$, differentiating it from the means of the male individuals $(\mathrm{U}=$ 21526; $\mathrm{p}<0.0001)$ and non-ovigerous females $(\mathrm{U}=7173$; $\mathrm{p}<0.0001)$. Juvenile individuals were abundant in the smaller size classes $(<2$ and 3-4 mm CC) (Figure 6).

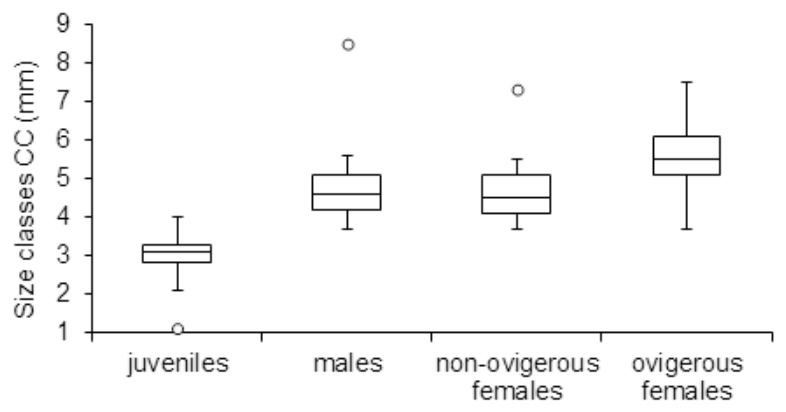

Figure 5. Average values of carapace length for each group of interest of Palaemon pandaliformis collected in an estuary in southeast Brazil between winter 2011 and autumn 2012. * Box and bar represent the quartiles, the highlighted line is the median and the point shows outliers.

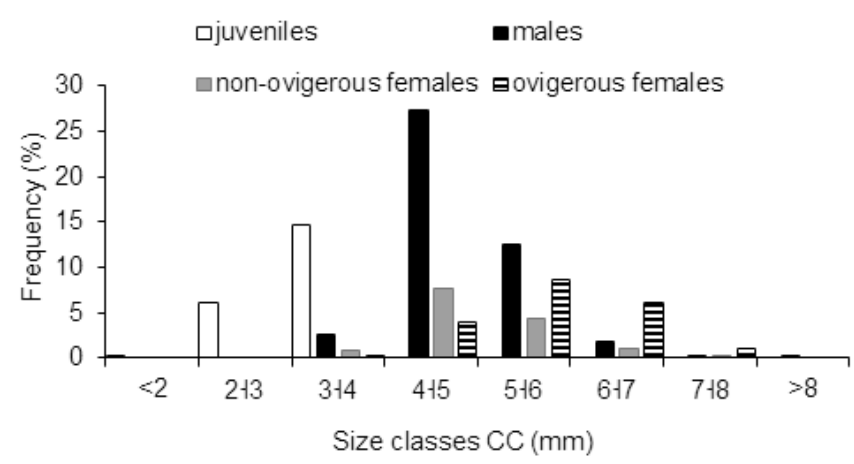

Figure 6. Frequency distribution of individuals in carapace length (CC) classes, for Palaemon pandaliformis collected in an estuary in southeast Brazil between winter 2011 and autumn 2012.

The sex ratio observed in the population of $P$. pandaliformis differed from that we expected (1:1) in favoring male individuals $(\widehat{\jmath} 1: 0.76$ 웅 $\left(X^{2}=14.47 ; \mathrm{GL}=1 ; \mathrm{p}=0.0001\right)$.

Throughout the seasons that comprised this study, we observed continuous recruitment through the presence of juveniles in all seasons (Figure 7a). Despite the large proportion of juveniles individuals in autumn 2012, this was also the season with the lowest total number of observed P. pandaliformis (26 juveniles and 1 adult). Ovigerous females were present in all seasons of the year, except for autumn 2012, a season in which we observed no female individuals (Figure 7b).

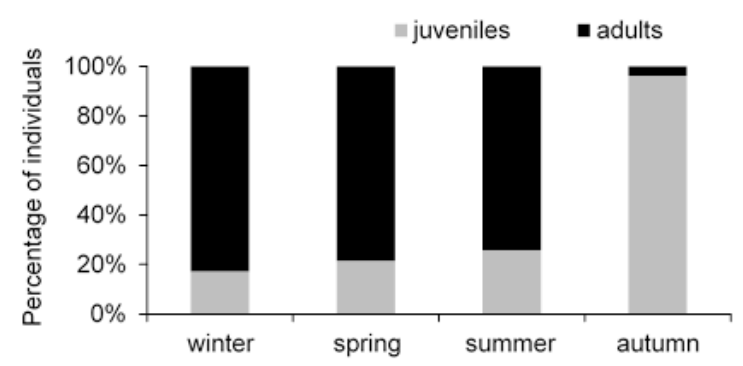

a)

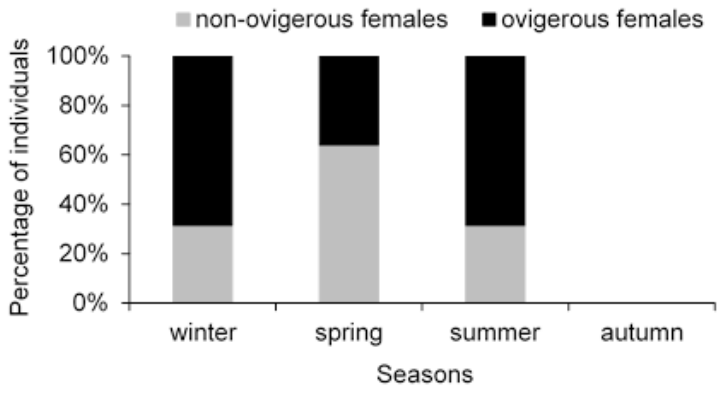

Figure 7. Percentage variation of juvenile and adult individuals (a). Percentage variation of non-ovigerous and ovigerous females (b) in the population of Palaemon pandaliformis collected seasonally in an estuary in southeast Brazil between winter 2011 and autumn 2012.

\section{Discussion}

The present study characterized the population structure of $P$. pandaliformis an environmentally important species of caridean shrimp, on which to date no work had been published in the state of Espírito Santo, Southeastern Brazil. The environmental characteristics of the estuary in the present study showed a positive association between water temperature and water salinity, with a gradual increase in these values throughout the winter (September 2011) and spring (November 2011) until reaching the highest levels in summer (March 2012). This pattern is typical of estuarine dynamics due to their geomorphology and differences in hydrodynamics, which result in constant changes of water temperature and salinity (Miranda et al. 2002).

The highest abundance of $P$. pandaliformis occurred in winter 2011 and spring 2011, decreasing as the water temperature increased over the collection periods. Rosa et al. (2015) observed for subtropical environments in a salt marsh in Paraná, peaks in number of caught individuals of $P$. pandaliformis in December and October, with no correlations with water temperature. This pattern was also observed for species of the genus Macrobrachium in the studies carried out by Mossolin \& Bueno (2002) and Fransozo et al. (2004). For subtropical and temperate environments, a pattern is described in which macrofaunal organisms have higher density values associated with the hottest months of the year (Emmerson 1985, Rosa \& Bemvenuti 2006). 
When comparing the relationship of the abundance of $P$. pandaliformis in two rivers (Rio Ubatumirin and Rio Comprido) with environmental factors, Mortari \& Negreiros-Fransozo (2007) found a correlation with temperature only in the population of the Rio Comprido. Mortari et al. (2009) reported a correlation between salinity and abundance of palaemonids, especially in relation to ovigerous females during the reproductive period. Rosa et al. (2015) did not observe a correlation between abundance of this species and water temperature, but described a negative correlation with salinity. In this sense, although the present study has not shown a correlation between abundance and environmental factors, it is clear that the abundance of this group of organisms is related to environmental factors, since salinity generally functions as an important regulator of the abundance of these macrocrustaceans in estuarine environments (Teixeira \& Sá 1998). On the other hand, temperature is another dynamic factor in this environment, which occasionally influences abundance, as it directly interferes with the physiology of crustaceans (Wear 1974, Melo \&Veloso 2005), especially since this species is distributed both in fresh water and in estuaries (Bond-Buckup \& Buckup 1989), having a great osmoregulatory capacity (Freire et al. 2003).

The sex ratio observed in the population of $P$. pandaliformis differed from what we expected (1:1), with a predominance of male individuals, similar to the findings in tropical freshwater environments documented by Paschoal et al. (2013) and Paschoal et al. (2016). Müller et al. (1999), Lima \& Oshiro (2002), Mortari et al. (2009) and Rosa et al. (2015) on the other hand found a predominance of females in the populations they observed - a pattern also documented in studies of other freshwater carideans (Mossolin \& Bueno 2002) on Macrobrachium olfersii (Wiegmann, 1836), Mantelatto \& Barbosa (2005) with $M$. brasiliense (Heller, 1862), Sampaio et al. (2007) with M. amazonicum (Heller, 1862) and Soares et al. (2015) with M. jelskii (Miers, 1877). Rosa et al. (2015) suggested that the predominance of females seems to be a common characteristic for the populations of $P$. pandaliformis. However, for Wenner (1972) and Kim (2005), the difference in sex ratio in the population may be related to the mortality rates between males and females. Other factors can also influence this ratio, such as the rate of seedlings, dispersion, reproduction (Botelho et al. 2001), migration, habitat preference (Collins et al. 2006) and even predation by birds and fish, who aim especially for non-ovigerous and ovigerous females palaemonids (Soares et al. 2015).

In the comparison of the carapace length, the ovigerous females of P. pandaliformis had the highest averages, differing statistically from the males. Larger sizes in females are also reported in studies by Müller et al. (1996), Lima \& Oshiro (2002), Paschoal et al. (2013) and Rosa et al. (2015). The males of $P$. pandaliformis do not defend the females and are not considered territorial, so that there is no need for energy expenditure for a body size increase, leaving more energy to produce sperm for reproduction (Paschoal et al. 2013). In females, on the other hand, the larger size of the abdomen and pleura contribute to a larger incubator chamber for the protection of their eggs during the incubation period (Paschoal et al. 2013).

The occurrence of sexually undifferentiated and immature (juvenile) individuals in the smaller size classes as well as the marked presence of adults from the medium size classes indicate a continuous population growth (Mattos \& Oshiro 2009). Another pattern we observed was the occurrence of juveniles during all seasons, but with a predominance in the winter months, where a lower water temperature was recorded.
Mattos \& Oshiro (2009), who studied M. potiuna (Müller, 1880), suggested that recruitment is related to water temperature: since the colder waters exhibit higher levels of oxygenation, which favors high metabolic rates, they provide a better environment for the development of these caridean, while in periods of higher temperatures, there may be a reduction or absence of juveniles in the population - a pattern we also found in the present study.

Females with eggs adhered to their pleopods were observed in almost all seasons of the year, with the exception of autumn, presenting higher catch frequencies in winter and spring - this suggests a pattern of seasonal-continuous reproduction of the population of $P$. pandaliformis in the river Rio Itapemirim. According to Pinheiro \& Fransozo (2002), a reproduction pattern is defined as seasonal-continuous when crustacean ovigerous females are recorded throughout the year, but with higher peaks in certain months; on the other hand, if these ovigerous females with or without developed gonads occur only in certain seasons and are absent in others, it is considered seasonal reproduction. The seasonal-continuous pattern has been observed in the estuarine regions of southeastern Brazil by Lima \& Oshiro (2002) and Mortari et al. (2009) as well as in a tropical river system by Paschoal et al. (2013). On the other hand, Müller et al. (1996) and Rosa et al. (2015) observed a seasonal reproductive pattern for the same species, associating it to the hottest periods of the year in subtropical regions.

In this sense, we can conclude that the river Rio Itapemirim presents favorable conditions for the population establishment of $P$. pandaliformis. The abundance of this species was more accentuated in the period between September and November. The population was in balance with a constant recruitment of juveniles in the smallest size classes and presence of mature individuals from the intermediate classes, thus suggesting a continuous population growth, in addition, we observed the presence of ovigerous females in almost all seasons, thus, with based these results, suggesting a pattern of seasonalcontinuous reproduction. This study is the first of its kind on this species in the state of Espírito Santo, and contributes to a better understanding of the species on a regional scale, as well as of the region of southeastern Brazil as a whole. We provide basic information on the behavior and adaptation of these shrimp in different habitats. In addition, these studies can serve as a tool for conservation and ecosystem management, since the shrimp are an important part of the trophic chain in rivers and estuaries, which are often integrated into large urban centers.

\section{Author Contributions}

Pedro Laino: Substantial contribution in the concept and design of the study; Contribution to data collection; Contribution to data analysis and interpretation; Contribution to manuscript preparation; Contribution to critical revision, adding intelectual contente.

Joelson Musiello-Fernandes: Substantial contribution in the concept and design of the study; Contribution to data analysis and interpretation; Contribution to manuscript preparation.

Adriane Araujo Braga: Substantial contribution in the concept and design of the study; Contribution to data analysis and interpretation; Contribution to manuscript preparation. 


\section{Conflicts of interest}

The authors declare that they have no conflict of interest related to the publication of this manuscript.

\section{References}

ANGER, K. \& MOREIRA, G.S. 1998. Morphometric and reproductive traits of tropical caridean shrimps. J. Crustac. Biol. 18(4):823-838.

BAUER, R.T. 2004. Remarkable shrimps: natural history and adaptations of the carideans. University of Oklahoma Press, Norman, p. 282.

BOND-BUCKUP, G. \& BUCKUP, L. 1989. Os Palaemonidae de águas continentais do Brasil Meridional (Crustacea, Decapoda). Res. Bras. Biol. 49(4):883-896.

BOTELHO, E.R.O., SANTOS, M.C.F. \& SOUZA, J.R.B. 2001. Aspectos populacionais do Guaiamum, Cardisoma guanhumi Latreille, 1825, do estuário do Rio Una (Pernambuco - Brasil). Bol. tec. cient. CEPENE 9(1):123-146.

CARVALho, H.A., GOMES, M.G.S., GONDIM A. Q., PEREIRA, M.C.G. 1979. Sobre a Biologia do Pitu - Macrobrachium acanthurus (Wiegmann, 1836) em Populações Naturais da Ilha de Itaparica. Universitas. 24:25-45.

COLLINS, P., GIRI, F., WILLINER, V. 2006. Population dynamics of Trichodactylus borellianus (Crustacea Decapoda Brachyura) and interactions with the aquatic vegetation of the Paraná River (South America, Argentina). Ann Limnol-Int. J. Lim. 42(1): 19-25.

COSTA, T.M., NEGREIROS-FRANSOZO, M.L. 2003. Population biology of Uca thayeri Rathbun, 1900 (Brachyura, Ocypodidae) in a Subtropical South American Mangrove area: results from transect and catch-per-unit-efforttechniques. Crustaceana. 75(10):1201-1218.

EMMERSON, W.D. 1985 Seasonal abundance, growth and production of Palaemon pacificus (Stimson) in eastern Cape tidal pools. S. Afr. J. zool. 20: 221-231.

FERREIRA, R.S., VIEIRA, R.R.R., D'INCAO, F. 2010. The marine and estuarine shrimps of the Palaemoninae (Crustacea: Decapoda: Caridea) from Brazil. Zootaxa. 2606: (1-14) 24.

FRANSOZO, A., RODRIGUES, F.D., FREIRE, F.A.M., COSTA, R.C. 2004. Reproductive biology of the freshwater prawn Macrobrachium iheringi (Ortmann, 1897) (Decapoda: Caridea: Palaemonidae) in the Botucatu region, São Paulo, Brazil. Nauplius. 12(2):119-126.

FREIRE, C.A., CAVASSIN, F., RODRIGUES, E.N., TORRES, A.H., McNAMARA, J.C. 2003. Adaptive patterns of osmotic and ionic regulation, and the invasion of fresh water by the palaemonid shrimps. Comp. Biochem. Phys. A. 136(3):771-778.

HAMMER, O., HARPER, D.A.T., RYAN, P.D. 2001. Past: paleontological statistics software package for education and data analysis. Palaeontol. Electronica. 4(1):1-9.

KIM, S. 2005. Population structure, growth, mortality, and size at sexual maturity of Palaemon gravieri (Decapoda: Caridea: Palaemonidae). J. crustac. Bol. 25:226-232.

LIMA, G.V. \& OSHIRO, L.M.Y. 2002. Aspectos reprodutivos de Palaemon pandaliformis (Stimpson, 1871) (Crustacea, Decapoda, Palaemonidae) no Rio Sahy, Mangaratiba, Rio de Janeiro, Brasil. Rev. Bras. Zool. 19(3): 855-860.

MANTELATTO, F.L.M. \& BARBOSA, L.R. 2005. Population structure and relative growth of freshwater prawn Macrobrachium brasiliense (Decapoda, Palaemonidae) from São Paulo State, Brazil. Acta Limnol. Bras. 17(3), 245-255.

MATTOS, L.A. \& OSHIRO, L.M.Y. 2009. Estrutura populacional de Macrobrachium potiuna (Crustacea, Palaemonidae) no Rio do Moinho, Mangaratiba, Rio de Janeiro, Brasil. Biota Neotropica. 9(1):81-86. https:// doi.org/10.1590/S1676-06032009000100010 (last access on 16/02/2020)

MELO, G.A.S. 2003 Manual de identificação dos crustáceos Decapoda de água doce do Brasil. São Paulo: Loyola/FAPESP, 429p.
MELO G.A.S. \& VELOSO V.G. 2005. The Brachyura (Crustacea, Decapoda) of coast of the State of Paraíba Brazil, collected by Project Algas. Rev. Bras. Zool. 22(3), 796-805.

MIRANDA, L.B., CASTRO, B.M. \& KJERFVE, B. 2002. Princípios de oceanografia física de estuários. EDUSP, São Paulo. p. 417.

MORTARI, R.C. \& NEGREIROS-FRANSOZO, M.L. 2007. Composition and abundance of the caridean prawn species in two estuaries from the northern coast of São Paulo State, Brazil. Acta Limnol. Bras. 19(2): 211-219.

MORTARI, R.C., PRALON, B.G.N., NEGREIROS-FRANSOZO, M.L. 2009. Reproductive biology of Palaemon pandaliformis (Stimpson, 1871) (Crustacea, Decapoda, Caridea) from two estuaries in southeastern Brazil. Invertebr. Reprod. Dev. 53(4) 223-232.

MOSSOLIN, E.C. \& BUENO, S.L.S. 2002. Reproductive biology of Macrobrachium olfersi (Decapoda, Palaemonidae) in São Sebastião, Brazil. J. crustac. Bol. 22:367-376.

MÜLLER, Y.M.R., NAZARI, E.M., BRESSAN, C., AMMAR, D. 1996. Aspectos da reprodução de Palaemon pandaliformis (Stimpson, 1871) (Decapoda, Palaemonidae) no Manguezal de Ratones, Florianópolis, Santa Catarina. Rev. Bras. Zool. 13(3):633-642.

MÜLLER, Y.M.R., NAZARI, E.M., AMMAR, D., FERREIRA, E.C., BELTRAME, I.T., PACHECO, C. 1999. Biologia dos Palaemonidae (Crustacea, Decapoda) da bacia hidrográfica de Ratones, Florianópolis, Santa Catarina, Brasil. Rev. Bras. Zool. 16(3):629-636.

PASCHOAL, L.R.P., GUIMARAES, F.J., COUTO, E.C.G. 2013. Relative growth and sexual maturity of the freshwater shrimp Palaemon pandaliformis (Crustacea, Palaemonidae) in northeastern of Brazil (Canavieiras, Bahia). Iheringia. Zool. 103(1):31-36.

PASCHOAL, L.R.P., GUIMARÃES, F.J., COUTO, E.C.G. 2016. Growth and reproductive biology of the amphidromous shrimp Palaemon pandaliformis (Decapoda, Caridea) in a Neotropical river from northeastern Brazil. Zoologia. 33(6):1-14.

PINHEIRO, M.A.A. \& FRANSOZO, A. 2002. Reproductive dynamics of the speckled swimming crab Arenaeus cribrarius (Lamarck, 1818) (Brachyura, Portunidae), on the north coast of São Paulo State, Brazil. J. crustac. Bol. 22(2):416-428.

ROSA, L.C. \& BEMVENUTI, C.E. 2006. Temporal variability of the estuarine macrofauna of the Patos Lagoon, Brazil. Rev. Biol. Mar. Oceanogr. 41:1-9.

ROSA, L.C., PASSOS, A.C., CORRÊA, M.F.M. 2015. Aspectos populacionais e reprodutivos de Palaemon pandaliformis (Crustacea: Palaemonidae) em uma marisma subtropical no Sul do Brasil. São Paulo. Bol. Inst. Pesca. 41(4):849-857

SAMPAIO, C.M.S., SILVA, J.A., SALES, S.P. 2007. Reproductive cycle of Macrobrachium amazonicum (Heller, 1862) females (Crustacea, Palaemonidae). Braz. J. Biol. 67(3):551-559.

SOARES, M.R.S., OSHIRO, L.M.Y., TOLEDO, J.C. 2015. Biologia reprodutiva de Macrobrachium jelskii (Crustacea, Decapoda, Palaemonidae) no Rio São Francisco, Minas Gerais, Brasil. Iheringia. Zool. 105(3): 307-315.

TEIXEIRA, R.L. \& SÁ, H.S. 1998. Abundância de macrocrustáceos decápodas nas áreas rasas do complexo lagunar Mundaú/Manguaba, AL. Res. Bras. Biol. 58(3): 393-494.

VALENTI, W.C., MELLO, J.T.C., LOBÃO, V.L. 1989. Fecundidade em Macrobrachium acanthurus (Wiegman, 1836) do Rio Ribeira do Iguape (Crustacea: Decapoda: Palaemonidae). Curitiba. Rev. Bras. Zool. 6(1):9-15.

WEAR, R.G. 1974. Incubation in British decapod Crustacea, and the effects of the temperature on the rate and success of embryonic development. J. Mar. Biol. Assoc. U.K. 54:745-762.

WENNER, A.M. 1972. Sex ratio as a function of size in marine Crustacea. Am. Nat. 106: 321-350.

ZAR, J.H. 2010. Biostatistical Analysis. 5th Edition. Pearson Prentice Hall, Upper Saddle River, NJ, p.944.

Received: $14 / 04 / 2020$

Revised: $21 / 07 / 2020$

Accepted: 27/08/2020

Published online: 05/10/2020 